The Vaccinators 



\section{The Vaccinators}

S M A L L P O X, M E D I C A L

K N O W L E D G E, A N D T H E

“O P E I N G" O F J A P A N

Ann Jannetta

S T A N F O R D U N I VERS I T Y PRES S

S T A N F O R D, C A L I F O R N I A 
Stanford University Press

Stanford, California

(C) 2007 by the Board of Trustees of the Leland Stanford Junior University. All rights reserved.

No part of this book may be reproduced or transmitted in any form or by any means, electronic or mechanical, including photocopying and recording, or in any information storage or retrieval system without the prior written permission of Stanford University Press.

The Japan Iron and Steel Federation Endowment Fund of the University of Pittsburgh provided a subvention to support the publication of this book

Printed in the United States of America on acid-free, archival-quality paper

Library of Congress Cataloging-in-Publication Data

Jannetta, Ann Bowman, I932-

The vaccinators : smallpox, medical knowledge, and the 'opening' of Japan / Ann Jannetta. p. ; cm.

Includes bibliographical references and index.

ISBN 978-0-8047-5489-7 (cloth : alk. paper)

ISBN 978-0-8047-8690-4 (pbk. : alk. paper)

I. Smallpox-Vaccination-Japan-History. 2. Smallpox vaccine-Japan-History. 3. Smallpox-Japan-History. I. Title.

[DNLM: I. Smallpox Vaccine-history-Japan. 2. Diffusion of Innovation-Japan. 3. History, I9th Century—Japan. 4. Smallpox-history-Japan. 5. Social Change-historyJapan. WC 588 J34v 2007]

RCi $83.7 . J 3 J 362007$

6I 4.5 '2 $10952-\mathrm{dc} 22$

2006035450

Typeset by inari in I I/I 4 Adobe Garamond 
For Evelyn and Thomas Rawski 
